\title{
Biodegradable-disposable containers made of Achira's leaves (Canna edulis) by thermoconforming
}

\author{
Sandra Acosta $^{1 *}$, Angeline Vargas ${ }^{1}$, Cesar Moreira ${ }^{1}$ \\ ${ }^{1}$ ESPOL Polytechnic University, Escuela Superior Politécnica del Litoral, Espol. Facultad de Ingenieria Mecánica y Ciencias de la \\ Producción. Campus Gustavo Galindo Km. 30.5 Vía Perimetral, P.O. Box 09-01-5863, Guayaquil, Ecuador. \\ *cacosta@espol.edu.ec, angkevar@espol.edu.ec, cemoreir@espol.edu.ec
}

\begin{abstract}
This study evaluates the feasibility of using Achira's leaves, plant native form Ecuador used by indigenous people for food cooking, as a raw material for the manufacture of disposable plates. For this purpose, the Achira's leaf was coated with a dispersion made of rice starch and gelatin in a 50:50 ratio with 2\% $(w / w)$ of solids content adding to this matrix an antimicrobial agent. The used films, the uncoated and the coated leaves were analyzed for its moisture, thickness and mechanical properties, also, for its structure using $X$-ray diffraction and response for microbial attack In-vitro and In-vivo. Results suggested that the Achira's laves are compatible with the active biodegradable coat used, due to a slight increment in the thickness of the leaves before and after application of the dispersion, additionally, the coating improves mechanical properties increasing the leaves elongation up to $40 \%$ which is desirable in materials subjected to process involving pressure and temperature. The $X$-ray diffraction values suggested that the matrix and the leaf may have a similar behavior in a thermoconforming process. Finally, the microbiological analysis performed suggested that the biodegrable active coating gives protection to the Achira's leaves.
\end{abstract}

Keywords-- rice starch, leaves, biodegradable utensils, essential oil orange.

\section{INTRODUCTION}

Plastic usage has been increasing exponentially since its beginnings, about 1950; for instance, by 1960 its production reached 15 million tons/year, rising to 330 million tons/year in 2014. Nevertheless, today only about $5 \%$ of the total produced is recovered by recycling [1]. The uncontrolled usage of plastics has provoked accumulation and serious damage in ecosystems, due to the long time it requires for degradation (i.e. 10 to 100 years).

In Ecuador, the use of plastics was about 350 thousand metric tons, in 2011, from it $0.77 \%$ corresponded to disposable utensils [2], almost all of them made of oil-based plastics. Despite of the increasing consciousness on the negative effects of fossil derived utensils, such as, containers, bags and other articles to the environment; they are still present in our daily lives, mainly due to their cost, durability and other properties of appealing interest to the industry. As a possible solution, the use of biodegradable materials has been

Digital Object Identifier (DOI):

http://dx.doi.org/10.18687/LACCEI2019.1.1.358

ISBN: 978-0-9993443-6-1 ISSN: 2414-6390 proposed [3], lately including plants, tree leaves and fibers, targeting the developing of eco-friendly materials and products and aiming reducing the pollution produced by the accumulation of disposable materials [4].

In the late years, several studies have been proposing producing and using biodegradable materials from polysaccharides, because of their chemical, physical and mechanical properties are similar to those of the oil-based articles, for its application as films or vessels [5] [6]. Starch is a widely known polysaccharide, it is abundant, renewable and it can be obtained from many different sources [7] [8] [9]. For illustration, rice starch which are high in amylose $(30-40 \%)$ [10] [8], may give good mechanicals (i.e. traction force and young modulus) [11] and low barrier properties to high polarity compounds [5], in addition, good stability and high viscosity [12]. On the other hand, this starch is highly hydrophilic and needs certain treatments to overcome it, one of the common treatments is the starch modification and the mix with other biopolymers.

Furthermore, films made with this polysaccharide needs the addition of a plasticizer to improve its flexibility and extensibility properties [13], being glycerol the more popular, due to it improves extensibility and water vapor barrier properties, as well as, increases flexibility of the film [7] [14] rising the mobility among polymeric chains and reducing intermolecular forces [15] [16]. Another remarkable biopolymer, for its characteristics, is gelatin; films made using this material reported good oxygen and light barriers. It has been shown, that the mix of gelatin and starch (of any kind) improves the extensibility and resistibility of a film [17]. Additionally, it has been shown the compatibility between glycerol and gelatin because of the improved mechanical properties of the film, when the plasticizer was added [18]. Importantly, biodegradable films may incorporate in its formulation active compounds that improves its functional properties; being one of these, essential oils which adds antimicrobial properties to it [19]. Essential oils usually come from plants roots, rhizomes, fruit, bark, seeds [20] [21], and are complex mixtures of alcohols, phenols, esters, ethers, aldehydes, ketones, terpene compounds [22], widely used as coatings or films at postharvest or storage of fruit and vegetables [23] [24] [25] [18] [26] [27] [28]. The

$17^{\text {th }}$ LACCEI International Multi-Conference for Engineering, Education, and Technology: "Industry, Innovation, And Infrastructure for Sustainable Cities and Communities”, 24-26 July 2019, Jamaica. 
antimicrobial activity of essential oils is closely related to variety of their compounds, which are dependent of the biological specie from where they are extracted [29].

The aim of this work was investigating the feasibility of using Ecuador native's leaves, which possess a great variety of plants with leaves that can be utilized for manufacture of utensils using techniques such as thermoconforming [30] [31]; i.e. achira's leaves (Canna edulis), as a raw material for the manufacture of plates. Achira's leaves were selected due to are resistant to high temperature and possess good mechanical properties, long shelf life before losing its turgency and elasticity [32], characteristics that were enhanced with the use of a thermoconforming biopolymer and an essential oil. Also, this research tries to give rural economically depressed zones new ways of development, achira's leaves are available in two Ecuadorian provinces, Azuay and Loja [33]. Last but not least, this particular study is in agreement to the new trend in the market of making $100 \%$ biodegradable utensils to be used in countries with poor regulations toward the use of plastics [34] [35].

\section{MATERIALS AND METHODS}

\section{A. Materials}

Rice starch (A), gelatinization temperature $78^{\circ} \mathrm{C}$ from Emsland Group; bovine gelatin (G) $240^{\circ}$ Bloom, gelatinization temperature $50{ }^{\circ} \mathrm{C}$ from Merck; glycerol (GL) from Merck; potato dextrose agar (PDA) from Merck; 99\% saturated solution of magnesium nitrate hexahydrate from Acros Organics - USA; essential oil from orange (AEN) code 40.003/x from Aromcolor, achira's leaf (Canna edulis) from Loja province - Ecuador.

\section{B. Dispersion elaboration}

A $2 \%(w / w)$ aqueous solution of rice starch (A) was made dissolving it at $100{ }^{\circ} \mathrm{C}$ in a thermal bath (Thermo Scientific, 18902A, Germany) by 45 minutes. Additionally, a 2\% (w/w) aqueous solution of gelatin $(\mathrm{G})$ was made dissolving it at 80 ${ }^{\circ} \mathrm{C}$ in a hot plate (Ema, 215179, Germany) by 30 minutes. Then, the dispersion was elaborated by mixing the $2 \%(\mathrm{w} / \mathrm{w})$ aqueous solution " $\mathrm{A}$ " with the $2 \%(\mathrm{w} / \mathrm{w})$ of "G" in a ratio 50:50 (A:G), glycerol (GL) was added as plasticizer at $30 \%$ of total solids (TS). Then, essential oil of orange was incorporated to $\mathrm{A}: \mathrm{G}$ at $50 \%$ of $\mathrm{TS}$. The mix were homogenized by 4 minutes (IKA Dispersers T25 digital ULTRA TURRAX ${ }^{@}, 25 \mathrm{~N}-25 \mathrm{G}$, Germany) at $8000 \mathrm{rpm}$.

\section{Moisture}

The matrices and achira's leaves were taking out from the desiccator and cut in small pieces of about $50 \mathrm{~mm} \times 50 \mathrm{~mm}$, using an electronic balance it was weight about $2 \mathrm{~g}$ of each sample (Sartorius, Md120, Germany, $\pm 0,0001 \mathrm{~g}$ ); then the samples were placed in a stove (Thermo Scientific, Model 3511 , USA) at $60{ }^{\circ} \mathrm{C}$ until constant weight. Equation 1 was used to determine moisture; however, the procedure of matrices was different from that of leaves. The matrices were let it stay in the desiccator 7 days and in the case of the leaves sample it was practiced 24 and 72 hours after reception which was the maximum time the leaves can stand without present degradation; the assay was performed by triplicate.

$$
\% \text { Moisture }=\frac{\mathrm{W}_{3}-\mathrm{W}_{1}}{\mathrm{~W}_{2}-\mathrm{W}_{1}} \times 100 \%
$$

$\mathrm{W}_{1}=$ Weight of the boat

$\mathrm{W}_{2}=$ Weight of the boat + sample

$\mathrm{W}_{3}=$ Weight of the boat + dry sample

\section{E. Thickness}

To measure thickness a digital electronic micrometer (Starret A-IM-221, ST1327137, USA) was used, six repetitions were made, and the average was reported.

\section{F. $\quad X$-ray diffraction}

Standards of diffraction were obtained utilizing an X-ray diffractometer (PANalytical, Model X'Pert Pro, Netherlands). The software used in the equipment was X'Pert Data Collector, Version 2.2e. The samples were cut in disks of $40 \mathrm{~mm}$ of diameter, then mounted in a char base and analyzed between $2 \theta: 5^{\circ}$ y $2 \theta: 30^{\circ}$, using radiation $\mathrm{Cu} \mathrm{K} \alpha(\lambda: 1,542 \AA)$, $40 \mathrm{kV}$ y $40 \mathrm{~mA}$ with a step size of $0,05^{\circ}, 19$ seconds as step time, scanning speed of $0,32344 \%$ and $1 / 2$ grating.

\section{G. Mechanical properties}

A $10 \mathrm{kN}$ universal test frame (Shimadzu, AG-IS $10 \mathrm{kN}$, Japan) with a software "TRAPEZIUM X" Version 2.2 was used. Samples of $100 \times 25 \mathrm{~mm}$ were cut and placed in the load cell, the maximum force used was $35 \mathrm{~N}$, with a maximum elongation of $50 \mathrm{~mm}$ with a speed of $50 \mathrm{~mm} / \mathrm{min}$. The samples were evaluated for the Force $(\mathrm{N})$, Young modulus (ME), ultimate tensile stress $(\mathrm{MPa})$ and deformation until fracture $\mathrm{E}$ $(\%)$; four repetitions were made, and the average was reported.

\section{H. Microbiological analysis}

In-vivo. The dispersion AG-AEN was applied by aspersion (treatment) over the two sides of the achira's leaves; then, the aspersed leaves were placed over containers as shown in Fig.1.1 and let it dry with a flow of air at $22{ }^{\circ} \mathrm{C}$ for 72 hours. After the treatment, the leaves were observed for any development of mold. 
In vitro. After the treatment was applied over the achira's leaves, they were dried. Then, they were cut in pieces of $10 \mathrm{x}$ $10 \mathrm{~mm}$ and placed in petri dishes with PDA at $25{ }^{\circ} \mathrm{C}$. The leaves were left in the stove for 72 hours, and observed, for any microbial growth on or surrounding the leaves; a blank (achira's leaves without treatment) was performed.

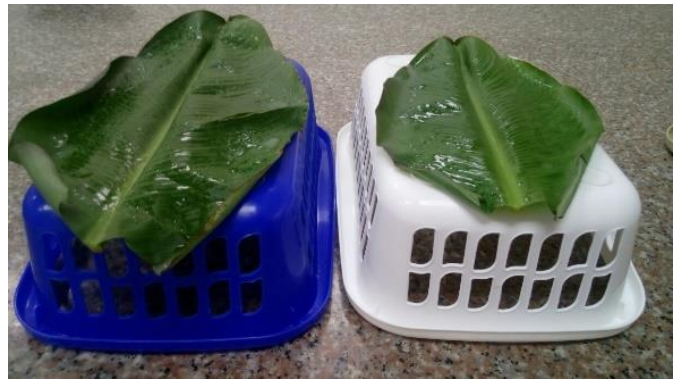

Fig. 1.1 Achira's leaves coated with AG-AEN dispersion

\section{Statistical analysis}

It was compared the media and standard deviation of the response variables by analysis of variance (ANOVA); it was used the software Minitab ${ }^{\circledR}$ 17.1.0 using a confidence interval of $95 \%$, and $p>0.05$ for significant difference. Results are expressed as super index a,b,c for significant difference among matrices.

\section{RESULTS}

\section{A. Moisture}

The results are shown in Table 1.1, as it can be seen there is a loss of moisture, up to $80 \%$, in the achira's leaves. The loss of water during storage is in agreement with the observation of the decreasing turgency of the leaves. These results are comparable to similar studies for plantain and stevia leaves where the moisture was 14 and $16 \%$ respectively. [36] [37]

Table 1.1 Achira’́s leaves moisture

\begin{tabular}{|c|c|c|}
\hline \multicolumn{3}{|c|}{ Moisture (\%)* } \\
\hline \multirow{2}{*}{$\begin{array}{c}\text { Achira's } \\
\text { leaves }\end{array}$} & \multicolumn{2}{|c|}{ Time (days) } \\
\cline { 2 - 3 } & $\mathrm{Ti}(0$ days $)$ & Tf (3 days) \\
\cline { 2 - 3 } & 16,31 & 27,67 \\
\hline
\end{tabular}

*Dry basis

The results shown in Table 1.2 are related to the biodegradable matrices, the superscript (a) indicates that there is not significate difference among their moistures. The moisture content of the matrices rises when " $G$ " is added, this may be due to the affinity of these material with water. Additionally, it was observed that the addition of AEN to the matrices reduced the moisture in about $14 \%$, may be due to AE forms small lipid globules that comes together, segregating and expelling water. Studies made by [38] [39] recommended a moisture about 5 to $10 \%$ to avoid an increment in water vapor permeability (WVP) diminishing the film barrier. Other researchers when studying films based on pectin's extracts and essential oil of lemon reported $11 \%$ of moisture, much higher than the obtained in this study.

Table 1.2 Moisture of Matrices A; G; A:G; AG
\begin{tabular}{|l|l|}
\hline \multicolumn{2}{|c|}{ Moisture (\%) } \\
\hline Matrices & Time (7 days) \\
\hline A & $7,05(1,02)^{(\mathrm{a})}$ \\
\hline G & $8,51(0,31)^{(\mathrm{a})}$ \\
\hline A:G & $8,33(0,94)^{(\mathrm{a})}$ \\
\hline AG-AEN & $7,13(0,12)^{(\mathrm{a})}$ \\
\hline
\end{tabular}

\section{B. Thickness}

There were not significant differences ( $p>0.05)$ among the thickness of the achira's leaves without coating and the leaves coated with AG-AEN, as it may be seen in table 1.3. However, an increment of thickness of about $2.9 \%$ was registered in the coated leaves which indicates a good incorporation of the matrix to the leaf.

Table 1.3 Achira's leaves thicknes with and whitout coating

\begin{tabular}{|c|c|}
\hline \multicolumn{2}{|c|}{ Thickness $(\mu \mathrm{m})$} \\
\hline Achira's leaves & $375,59(10,86)^{(\mathrm{a})}$ \\
\hline $\begin{array}{c}\text { Achira's leaves + } \\
\text { AG-AEN }\end{array}$ & $387,06(9,34)^{(\mathrm{a})}$ \\
\hline
\end{tabular}

Table 1.4 shown the values of matrices thickness, it can be seen significant differences $(p<0.05)$ among the matrices. It was observed that the thickness of the film reduces about $12 \%$ when adding AEN, compared to the matrix A:G, suggesting that the AEN ease the elimination of cellular water resulting in a thickness decrement.

Table 1.4 Thickness of the matrices A; G; A:G; AG-AEN

\begin{tabular}{|c|c|}
\hline \multicolumn{2}{|c|}{ Thickness $(\mu \mathrm{m})$} \\
\hline Matrices & Time $(7$ days $)$ \\
\hline A & $100,35(1,00)^{(\mathrm{b})}$ \\
\hline G & $114,78(2,14)^{(\mathrm{a})}$ \\
\hline A:G & $103,73(2,65)^{(\mathrm{b})}$ \\
\hline A:G-AEN & $90,88(1,54)^{(\mathrm{c})}$ \\
\hline
\end{tabular}

Other researchers found that the thickness may vary upon the film composition, reporting a variety of results, for instance, films based on mango puree $150-200 \mu \mathrm{m}$, rice bran $190 \mu \mathrm{m}$, mango starch $127 \mu \mathrm{m}$, plantain starch $113 \mu \mathrm{m}$ [38] [40] [41] [42].

$17^{\text {th }}$ LACCEI International Multi-Conference for Engineering, Education, and Technology: "Industry, Innovation, And Infrastructure for Sustainable Cities and Communities”, 24-26 July 2019, Jamaica. 


\section{X-ray diffraction}

Starch possess a semi crystalline system [43] that could be detected by X-ray diffraction [44]. Starch granules are composed by amorphous zones, mainly amylose, and by crystalline zones composed of double bound chains of amylopectin [45], which can be detected by peaks during the analysis of the material, by X-ray diffraction. The A:G matrix were subjected to X-ray diffraction and the results are shown in fig. 1.3, there it can be seen two peaks, one for low diffraction at $8.2^{\circ}$ and one for high diffraction at $21^{\circ}$. When AEN is incorporated (Fig.1.4) there it can be seen two peaks, one for low diffraction at $8.5^{\circ}$ and one for high diffraction at $20.5^{\circ}$.In their studies [46] [47] reported peaks for starch at $15^{\circ}, 18^{\circ}$ and $23^{\circ}$. These peaks vary depending on the amylose of the analyzed sample. Furthermore, for films based on rice starch [48] reported peaks at $17.08^{\circ}$ and $19.58^{\circ}$; values close to the reported in the present study for the "A" matrix. In the case of bovine gelatin, it was reported by [47] values of $2 \Theta$ between 20 and $22.5^{\circ}$ which are in agreement with the reported by [49] [50]. Blending the matrices will provoke superposed peaks as seen in matrix A:G.

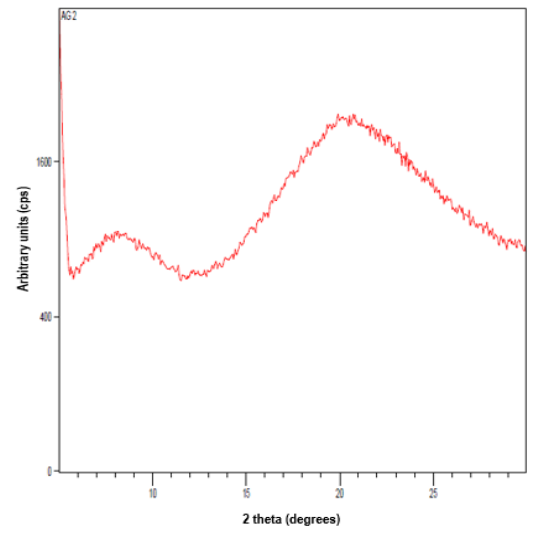

Fig. 1.3 X-ray Diffraction of A:G matrices

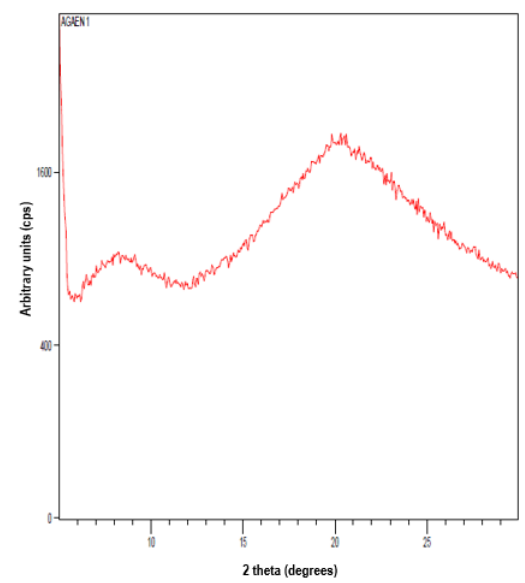

Fig. 1.4 X-ray diffraction of AG:AEN matrices
The X-ray diffraction performed in achira's leaves shown two peaks, one at $8^{\circ}$ similar to the found in the AGAEN matrix and another with higher amplitude and height between $28^{\circ}$ and $30^{\circ}$, presenting amorphous zones beginning from $35^{\circ}$. These close values suggested that the matrix and the leaf might have a similar behavior in a thermoconforming process.

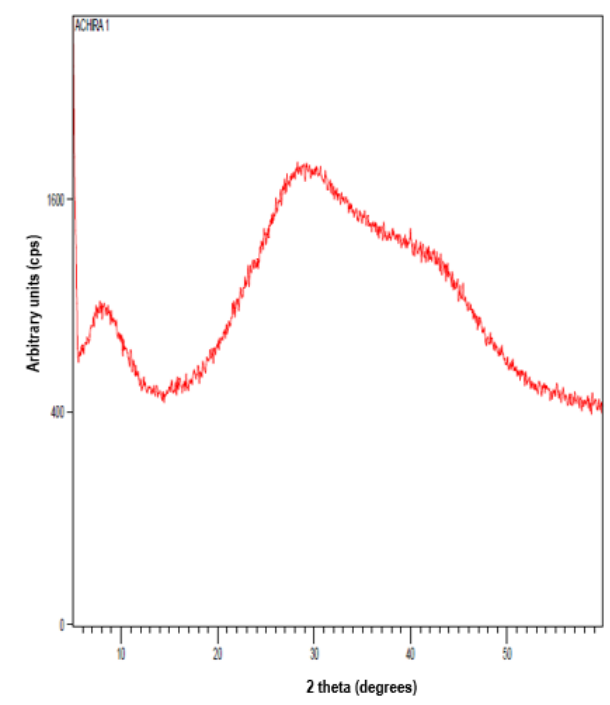

Fig.1.5 X-ray diffraction of achira's leaf

\section{Mechanical properties}

The mechanical properties of the achira's leaves with and without the active biodegradable coating are displayed in Table 1.5

Table 1.5 Mechanical properties $\mathrm{F}(\mathrm{N})$, Young modulus (ME), ultimate tensile strength (TS) and deformation until fracture (\%E) in achira's leaf coated and

\begin{tabular}{|c|c|c|c|c|}
\hline & $\begin{array}{c}\text { Force } \\
\text { Leaf }\end{array}$ & $\begin{array}{c}\text { Young } \\
\text { modulus } \\
(\mathrm{Npa})\end{array}$ & $\begin{array}{c}\% \\
\mathrm{E}\end{array}$ & $\begin{array}{c}\text { TS } \\
(\mathrm{Mpa})\end{array}$ \\
\hline $\begin{array}{c}\text { Achira's } \\
\text { leaves }\end{array}$ & $7,39(1,27)^{(\mathrm{a})}$ & $0,71(0,175)^{(\mathrm{a})}$ & $10,32(1,52)^{(\mathrm{a})}$ & $0,90(0,05)^{(\mathrm{a})}$ \\
\hline $\begin{array}{c}\text { Achira's } \\
\text { leaves + AG- } \\
\text { AEN }\end{array}$ & $5,12(0,70)^{(\mathrm{b})}$ & $0,315(0,13)^{(\mathrm{b})}$ & $14,60(1,60)^{(\mathrm{b})}$ & $1,04(0,52)^{(\mathrm{a})}$ \\
\hline
\end{tabular}

As it can be seen, there is an increment in $\% \mathrm{E}$ of about $29.31 \%$ in the coated achira's leaf; suggesting, that the coating contributes elasticity to the leaf. However, the parameter force $(\mathrm{N})$ is where it can be seen a difference between the coated and uncoated leaf (fig. 1.6).

$17^{\text {th }}$ LACCEI International Multi-Conference for Engineering, Education, and Technology: "Industry, Innovation, And 
values of TS are higher and the values of \% $\mathrm{E}$ are lower [55].

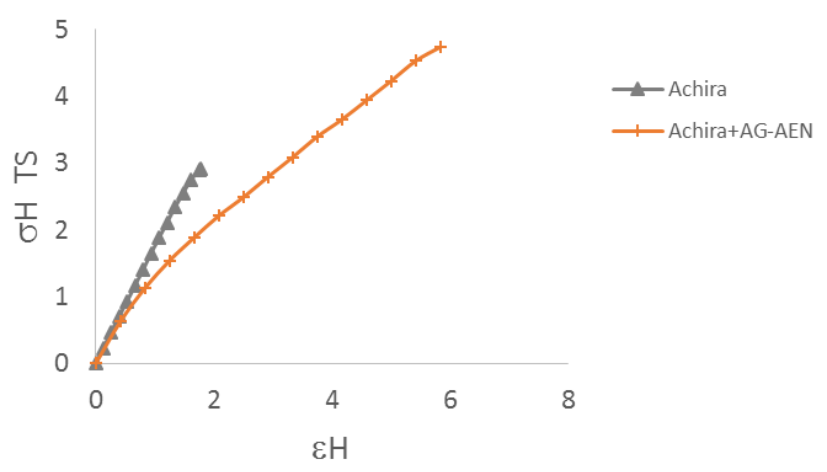

Fig. 1.6 Force vs distance of achira's leaf coated and uncoated

The mechanical properties, i.e. Force (F), Young modulus (ME) and ultimate tensile strength (TS), between matrices are significantly different $(\mathrm{p}<0.05)$ as shown in Table 1.6. Matrix " $A$ " values are small compared to those of matrix " $G$ "; however, certain studies report higher values, than the reported in this study, for " $\mathrm{A}$ ". For instance, 1.6 MPa for TS and 21.3 MPa for ME reported by [51] [52] that can be explained due to the different content in total solids. When analyzing the matrix " $A: G$ " it was found that the values lean toward those of matrix " $G$ " a possible reason is because gelatin possess stronger bonds in its structure. Nevertheless, when AEN is added to the matrix it was observed a reduction in values of $\mathrm{F}$ (about 29\%), TS (about 19\%) and ME (about 23\%), suggesting that when an essential oil is added to the matrix, these loss strengths but gain elasticity. This result is in agreement with the observed by [53] who reported an increment in the deformation capacity of the films made of zein when incorporating essential oils of oregano, carvacrol, clove and eugenol due to an increasing mobility of these essential oils, in the zein polymeric chains. On the other hand, studies made by [39] using essential oil of bergamot, lemon and tea reported a decreasing value of the cited mechanical properties. Other studies, has reported no changes in the mechanical properties of the film when adding concentrations of $100 \mu \mathrm{l} / \mathrm{g}$ of garlic essential oil in chitosan films [47] [54] possibly due to the used matrix. In addition, experiments using chitosan matrix has reported different behaviors with respect to values of TS and \% E when adding essential oils of rosemary and thymus; a low concentrations of thymus essential oil makes the value of TS decrease and the value of $\% \mathrm{E}$ increase. Meanwhile, when adding rosemary essential oil the value of TS rise and the value \% E decrease Interestingly, when increasing the concentrations of both essential oils and its blends rosemary : thymus the
Table 1.6 Mechanical properties of matrices A, G, A:G and AG-

\begin{tabular}{|l|l|l|l|l|}
\hline Matrix & Force $(\mathrm{N})$ & $\begin{array}{l}\text { ME } \\
(\mathrm{MPa})\end{array}$ & $\begin{array}{l}\text { TS } \\
(\mathrm{MPa})\end{array}$ & $\% \mathrm{E}$ \\
\hline A & 2.34 & 0.93 & 0.58 & 64.58 \\
& $(0.48)^{\mathrm{b}}$ & $(0.19)^{\mathrm{b}}$ & $(0.21)^{\mathrm{b}}$ & $(5.42)^{\mathrm{a}}$ \\
\hline G & 15.33 & 5.35 & 4.43 & 24.91 \\
& $(1.26)^{\mathrm{a}}$ & $(0.37)^{\mathrm{a}}$ & $(0.79)^{\mathrm{a}}$ & $(1.40)^{\mathrm{c}}$ \\
\hline A:G & 14.70 & 5.65 & 5.63 & 23.95 \\
& $(3.39)^{\mathrm{a}}$ & $(0.73)^{\mathrm{a}}$ & $(0.79)^{\mathrm{a}}$ & $(3.33)^{\mathrm{c}}$ \\
\hline AG - AEN & 10.34 & 4.57 & 4.32 & 43.63 \\
& $(2.39)^{\mathrm{a}}$ & $(0.93)^{\mathrm{a}}$ & $(1.33)^{\mathrm{a}}$ & $(3.08)^{\mathrm{b}}$ \\
\hline
\end{tabular}

[56] [14] reported as well, a decreasing values in mechanical properties when adding cinnamon, orange, clove, and pepper essential oils to a cassava matrix.

Being the value of force $(F)$ parameter lower for matrix " $A$ ", similar for "G" and "A:G" and when the AEN is added the value lies between "AG" and "G" (Fig. 1.7).

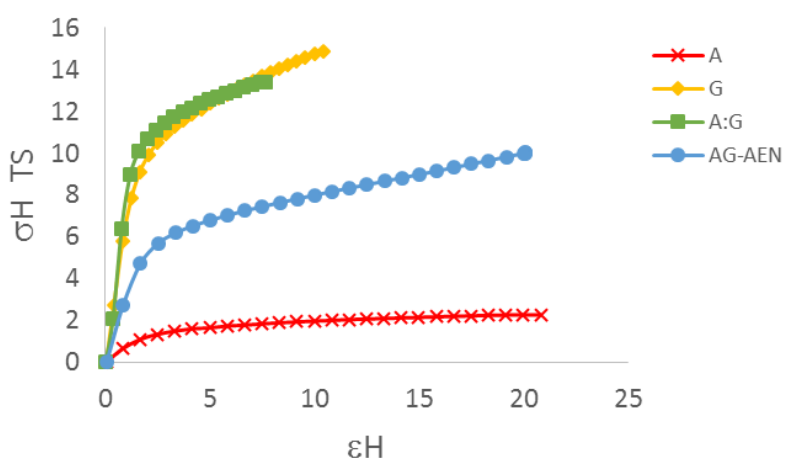

Fig. 1.7 Force vs distance, matrices A, G, A:G and AG - AEN

E. Microbiological analysis

$17^{\text {th }}$ LACCEI International Multi-Conference for Engineering, Education, and Technology: "Industry, Innovation, And Infrastructure for Sustainable Cities and Communities”, 24-26 July 2019, Jamaica. 


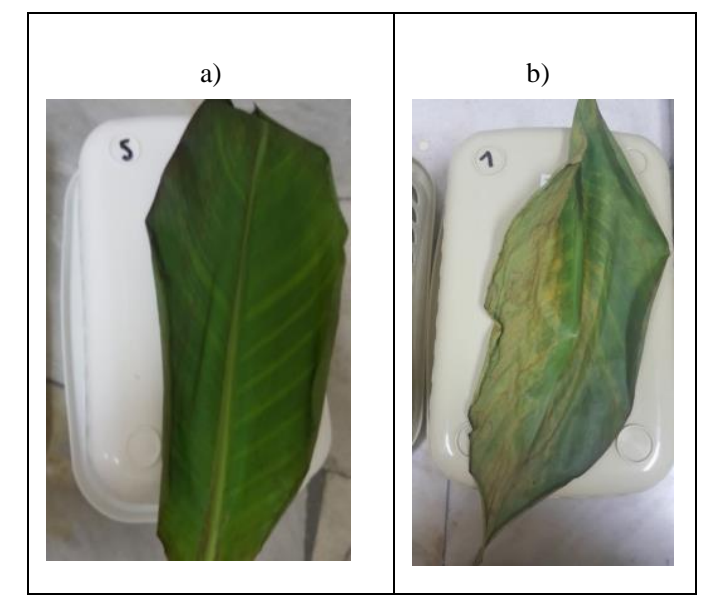

Fig. 1.8 In-vivo assay a) Achira $+A G-A E N$ b) uncoated achira's leaf

In-vivo. After 3 days, the achira's leaf coated with AGAEN biodegradable active coating was not attacked by microorganisms (Fig. 1.8.a), meanwhile, the uncoated leaf presented turgency loss (Fig. 1.8.b)

In-vitro. After 3 days, the uncoated achira's leaf presented mold growth over and surrounding the leaf (Fig. 1.9.a), when taken the leaf for observation under microscope it was identified as the fungus Penicillium $s p$. On the other hand, the coated achira's leaf did not developed any kind of microorganisms; suggesting that the coating possess a positive inhibitor behavior (Fig. 1.9.b). The observed results are in agreement with the results of [57] who reported a inhibition in the growth of Rhizopus stolonifer in papaya when using concentration of $0.1 \%$ of thymus essential oil. Also, [27] when working with strawberries coated with chitosan and using oleic acid as fungistatic agent, reported that the presence of fungi during storage decreased at high concentration of oleic acid. Additionally, [58] shown the inhibitory effect of oregano essential oil in Aspergillus nigger and Penicillum sp. when working with chitosan, corn and amaranth based films; another study reported antifungal effects of the oregano essential oil, in a concentration of $1000 \mathrm{ppm}$, to fully inhibit the growth of the fungus Colletotrichum gloeosporioides in cucumbers [59]. Furthermore, [29] studied the antifungal activity, using in-vivo assays, of eucalyptus essential oil over the development of the fungus Botrytis cinerea in raspberries; his results suggested that concentrations over 2000 ppm inhibited $42 \%$ of the mycelial growth, therefore, suggesting the use of this essential oil to reduce the degradation on the fruit. Studies reported by [39] suggested that certain compounds of bergamot essential oil were loss or evaporated during the chitosan matrix preparation and drying, reducing its antimicrobial effect. Also, reported that at high concentrations the essential oil had longer effects, in storage, against the growth of Penicillium $s p$.

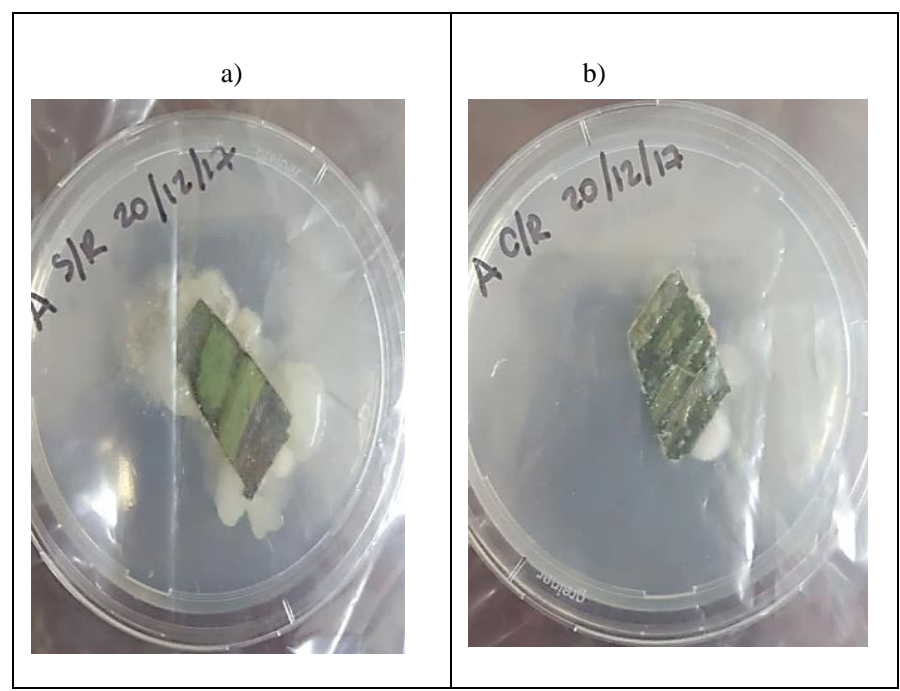

Fig. 1.9 In-vitro assay a) Achira b) Achira $+A G-A E N$

\section{CONCLUSIONS}

We can conclude that there are differences in the mechanical properties among the different formulated matrices. Also, it was observed that the active biodegradable coating over achira's leaves increase the $\% \mathrm{E}$ in about $29.31 \%$, therefore, increasing its flexibility. Regarding to thickness and moisture, there are no statistically significant difference between the coated and uncoated leaves, however, a small increment in thickness was registered, of about $2.9 \%$, after the application of the dispersion indicates a good incorporation of the matrix AG - AEN to the leaf. Furthermore, the X-ray diffraction analysis shown similar peaks, one at $8^{\circ}$ similar to the found in the AG-AEN matrix and another with higher amplitude and height between $28^{\circ}$ and $30^{\circ}$, presenting amorphous zones beginning from $35^{\circ}$. These close values suggested that the matrix and the leaf may have a similar behavior in a thermoconforming process. Last but not least, the microbiological assays suggested that the applied active biodegradable coating helped in protecting the leaf against microorganisms, i.e. the fungus Penicillium $s p$ and therefore increasing the leaf shelf life. From the obtained results we can deduce that is feasible the production of utensils, i.e. disposable plates, using as a matrix achira's leaves and the dispersion $\mathrm{AG}-\mathrm{AEN}$ as coating to preserve it and improving its thermoconforming properties.

\section{REFERENCES}

[1] Vásquez, L. (2016). Plástico Desechable. Retrieved from: http://www.nacion.com/revista-dominical/plastico-desechable-unasesino-silencioso/VFLRFTV5KZGXHC3QSDHTTR5H3U/story/

[2] FLACSO-MIPRO. (2011). Elaboración de artículos plásticos para el hogar. Boletín mesual de análisis sectorial de MIPYMES. Retrieved from https://www.flacso.edu.ec/portal/pnTemp/PageMaster/1ek76ttdig4 y5etomj1ag3t7vqou 89.pdf 
[3] Moreira, C., Koppar A., Pullammanappallil P., Welt B. (2016). Steam Treatment of waste Polylactid acid (PLA) based products for lactic acid recovery. 14th Latin American and Caribbean Consortium of Engineering Institutions (LACCEI) International Multi-Conference for Engineering, Education, and Technology, San José https://dx.doi.org/10.18687/LACCEI2016.1.1.354

[4] Vargas, C., Costa, T., Rios, A., \& Flores, S. (2017). Comparative study on the properties of films based on red rice (Oryza glaberrima) flour and starch. Food Hydrocolloids,65,96-106. https://doi.org/10.1016/j.foodhyd.2016.11.006

[5] Laohakunjit, N., \& Noomhorm, A. (2004). Effect of plasticizers on mechanical and barrier properties of rice starch film. Starch/Staerke, 56(8), 348-356. https://doi.org/10.1002/star.200300249

[6] Villada, H., Acosta, H. A., \& Velasco, R. J. (2007). Biodegradables biopolymers naturals used in biodegradable. Polymer, 12(4), 5-13. Retrieved from http://www.unicordoba.edu.co/revistas/rta/documentos/12-2/1221.pdf

[7] Domínguez, M., \& Jiménez, M. (2012). Películas comestibles formuladas con polisacáridos : propiedades y aplicaciones. Temas Selectos de Igeniería de Alimentos, 2, 110-121.

[8] Khunae, P., Tran, T., \& Sirivongpaisal, P. (2007). Effect of heatmoisture treatment on structural and thermal properties of rice starches differing in amylose content. Starch/Staerke, 59(12), 593599. https://doi.org/10.1002/star.200700618

[9] Tharanathan, R. . (2003). Biodegradable Polymers : Past, Present, and Future. Trends in Food Science and Technology 14, 300(3), 71-78. https://doi.org/10.13031/2013.41300

[10] Cano, A., Jiménez, A., Cháfer, M., Gónzalez, C., \& Chiralt, A. (2014). Effect of amylose:amylopectin ratio and rice bran addition on starch films properties. Carbohydrate Polymers, 111, 543-555. https://doi.org/10.1016/j.carbpol.2014.04.075

[11] Bourtoom, T., \& Chinnan, M. S. (2008). Preparation and properties of rice starch-chitosan blend biodegradable film. LWT Food Science and Technology, 41(9), 1633-1641. https://doi.org/10.1016/j.lwt.2007.10.014

[12] Piyada, K., Warayou, S., \& Thawien, W. (2013). Mechanical, thermal and structural properties of rice starch films reinforced with rice starch nanocrystals. International Food Research Journal, 20(1), 439-449.

[13] Wittaya, T. (2012). Rice Starch-Based Biodegradable Films: Properties Enhancement. Structure and Function of Food Engineering, 103-134. https://doi.org/10.5772/47751.hancement

[14] Quintero, J., Falguera, V., \& Muñoz, A. (2010). Películas y recubrimientos comestibles : importancia y tendencias recientes en la cadena hortofrutícola. Revista Tumbaga, 5, 93-118.

[15] Lu, D., Xiao, C., \& Xu, S. (2009). Starch-based completely biodegradable polymer materials. Express Polymer Letters, 3(6), 366-375. https://doi.org/10.3144/expresspolymlett.2009.46

[16] Alves, V. D., Mali, S., Beléia, A., \& Grossmann, M. V. E. (2007). Effect of glycerol and amylose enrichment on cassava starch film properties. Journal of Food Engineering, 78(3), 941-946. https://doi.org/10.1016/j.jfoodeng.2005.12.007

[17] Acosta, S., Jiménez, A., Cháfer, M., González-Martínez, C., \& Chiralt, A. (2015). Physical properties and stability of starchgelatin based films as affected by the addition of esters of fatty acids. Food Hydrocolloids, 49, 135-143. https://doi.org/10.1016/j.foodhyd.2015.03.015

[18] Al-Hassan, A. A., \& Norziah, M. H. (2012). Starch-gelatin edible films: Water vapor permeability and mechanical properties as affected by plasticizers. Food Hydrocolloids, 26(1), 108-117. https://doi.org/10.1016/j.foodhyd.2011.04.015

[19] De Aquino, A., Blank, A., \& De Aquino Santana, L. (2015). Impact of edible chitosan-cassava starch coatings enriched with Lippia gracilis Schauer genotype mixtures on the shelf life of guavas (Psidium guajava L.) during storage at room temperature. Food Chemistry, 171, 108-116. https://doi.org/10.1016/j.foodchem.2014.08.077

[20] Baser, K. H. C., \& Buchbauer, G. (2010). Handbook of Essential Oils Science, Technology, and Applications, 95-112. https://doi.org/doi:10.1201/9781420063165-c3

[21] Zekaria, D. (2007). Los aceites esenciales, una alternativa a los antimicrobianos. Laboratorios Calier, 1-6.

[22] Zurarte, M., \& Salgueiro, L. (2015). Bioactive Essential Oils and Cancer. Bioactive Essential Oils and Cancer, 1, 19-21. https://doi.org/10.1007/978-3-319-19144-7

[23] Ortega-Toro, R., Collazo-Bigliardi, S., Roselló, J., Santamarina, P., \& Chiralt, A. (2017). Antifungal starch-based edible films containing Aloe vera. Food Hydrocolloids, 72, 1-10. https://doi.org/10.1016/j.foodhyd.2017.05.023

[24] Ordoñez Bolaños, D. Y., Zuñiga Camacho, D., Hoyos Concha, J. L., Mosquera Sánchez, S. A., \& Mosquera Sánchez, L. P. (2014). Efecto de recubrimiento de almidón de yuca modificado y aceite de tomillo aplicado al pimiento (Capsicum annuum). Revista Mexicana de Ciencias Agrícolas, 5(5), 795-805. Retrieved from http://www.scielo.org.mx/scielo.php?script=sci_arttext\&pid=S200 7-09342014000500006

[25] Teixeira, B., Marques, A., Pires, C., Ramos, C., Batista, I., Saraiva, J. A., \& Nunes, M. L. (2014). Characterization of fish protein films incorporated with essential oils of clove, garlic and origanum: Physical, antioxidant and antibacterial properties. LWT - Food Science and Technology, 59(1), 533-539. https://doi.org/10.1016/j.lwt.2014.04.024

[26] Timóteo, N., Athayde, A. J., Vasconcelos, C. E., Veríssimo, C., de Melo e Silva, S., Sousa da Silva, R., ... Leite, E. (2012). Efficacy of the application of a coating composed of chitosan and Origanum vulgare $\mathrm{L}$. essential oil to control Rhizopus stolonifer and Aspergillus niger in grapes (Vitis labrusca L.). Food Microbiology, 32(2), 345-353. https://doi.org/10.1016/j.fm.2012.07.014

[27] Vargas, M., Albors, A., Chiralt, A., \& González-Martínez, C. (2006a). Quality of cold-stored strawberries as affected by chitosan-oleic acid edible coatings. Postharvest Biology and Technology, 41(2), 164-171. https://doi.org/10.1016/j.postharvbio.2006.03.016

[28] Reingold, E., Charness, N., Pomplun, M., \& Stampe, D. (2001). Effect of the potassium sorbate and carvacrol addition on the properties and antimicrobial activity of tapioca starch Hydroxypropyl methylcellulose edible films. Psychological Science, 321(December), 48-55. https://doi.org/10.1002/jlcr

[29] Trejo-Ramírez, V., Trejo-Márquez, M., Pascual, S., \& Lira, A. (2016). Extracción de aceite esencial de eucalipto y su aplicación como agente antifúngico en un envase activo para conservación de frambuesa. Investigación Y Desarrollo En Ciencia Y Tecnología de Alimentos, 1(1), 60-65.

[30] Andreuccetti, C. (2016). Native and Modified Gelatin Films Produced by Casting, Extrusion, and Blowing Extrusion Processes. Food Engineering Department, 8(1), 11-27.

[31] Sun, S., Song, Y., \& Zheng, Q. (2008). Morphology and mechanical properties of thermo-molded bioplastics based on glycerol-plasticized wheat gliadins. Journal of Cereal Science, 48(3), 613-618. https://doi.org/10.1016/j.jcs.2008.01.005

[32] Morocho, J. (2013). La achira y su aplicación en la cocina de tendencia vanguardista, $11-15$

[33] Novoa, M. (2006). Proyecto de factibilidad para la instalación de una planta procesadora de Almidón de Achira en la provincia de Loja, 11-15.

[34] EcoInventos. (2017). Platos desechables hechos de hojas. Retrieved from https://ecoinventos.com/platos-desechableshechos-de-hojas/

$17^{\text {th }}$ LACCEI International Multi-Conference for Engineering, Education, and Technology: "Industry, Innovation, And Infrastructure for Sustainable Cities and Communities", 24-26 July 2019, Jamaica. 
[35] Thorwarth, B., Fiechter, C., Stolz, D., \& Zolgadri, P. (2016). Platos hechos de hojas de plantas. Retrieved from http://leafrepublic.com/

[36] Martínez, C., Cayón, G., \& Ligarreto, G. (2016). Composición química y distribución de materia seca del fruto en genotipos de plátano y banano. Revista Corpoica Ciencia Y Tecnología Agropecuaria, 17(2), 217-227. https://doi.org/10.21930/rcta.vol17_num2_art:491

[37] Jeria, D., \& Pozo, A. (2011). Estudio Del Secado Convectivo De Hojas De Stevia Rebaudiana Y Factibilidad Técnico-Económica De Una Planta Elaboradora De Edulcorante a Base De Stevia. Universidad de Chile.

[38] Sánchez, D., Contreras-Esquivel, J., Nevárez-Moorillón, G., \& Aguilar, C. (2015). Caracterización de películas comestibles a base de extractos pécticos y aceite esencial de limón Mexicano. CYTA - Journal of Food, 13(1), 17-25. https://doi.org/10.1080/19476337.2014.904929

[39] Sánchez-González, L., Cháfer, M., Chiralt, A., \& GonzálezMartínez, C. (2010). Physical properties of edible chitosan films containing bergamot essential oil and their inhibitory action on Penicillium italicum. Carbohydrate Polymers, 82(2), 277-283. https://doi.org/10.1016/j.carbpol.2010.04.047

[40] Sothornvit, R., \& Pitak, N. (2007). Oxygen permeability and mechanical properties of banana films. Food Research International, 40(3), 365-370. https://doi.org/10.1016/j.foodres.2006.10.010

[41] Romero-Bastida, C., Bello-Pérez, L., García, M., Martino, M., Solorza-Feria, J., \& Zaritzky, N. (2005). Physicochemical and microstructural characterization of films prepared by thermal and cold gelatinization from non-conventional sources of starches. Carbohydrate $\quad$ Polymers, 60(2), 235-244. https://doi.org/10.1016/j.carbpol.2005.01.004

[42] Gnanasambadam, R., Hettiarachchy, N. S., \& Coleman, M. (1997). Mechanical and Barrier Properties of Rice Bran Films. Journal of Food Science, 62(2), 395-398. https://doi.org/10.1111/j.13652621.1997.tb04009.x

[43] Talja, R. (2007). Preparation and characterization of potato starch films plasticized with polyols. Forestry. Retrieved from http://scholar.google.com/scholar?hl=en\&btnG=Search\&q=intitle: Preparation+and+characterization+of+potato+starch+films+plastic ized+with+polyols\#0

[44] Amagliani, L., O’Regan, J., Kelly, A., \& O’Mahony, J. (2016). Chemistry, structure, functionality and applications of rice starch. Journal of Cereal Science, 70, 291-300. https://doi.org/10.1016/j.jcs.2016.06.014

[45] Luchese, C. L., Spada, J. C., \& Tessaro, I. C. (2017). Starch content affects physicochemical properties of corn and cassava starch-based films. Industrial Crops and Products, 109(May), 619626. https://doi.org/10.1016/j.indcrop.2017.09.020

[46] Zeng, J., Guanglei, L., Haiyan, G., \& Zhengang, R. (2011). Comparison of A and B starch granules from three wheat varieties. Molecules 16, 10570-10591.

[47] Acosta, S. (2014). Propiedades de films de Almidón de yuca y gelatina. Incorporaciòn de aceites esenciales con efecto antifungico. Universidad Politécnica de Valencia.

[48] Detduangchan, N., Sridach, W., \& Wittaya, T. (2014). Enhancement of the properties of biodegradable rice starch films by using chemical crosslinking agents. International Food Research Journal, 21(3), 1189-1199.

[49] Bergo, P., \& Sobral, P. J. A. (2007). Effects of plasticizer on physical properties of pigskin gelatin films. Food Hydrocolloids, 21(8), 1285-1289. https://doi.org/10.1016/j.foodhyd.2006.09.014

[50] Rivero, S., García, M. A., \& Pinotti, A. (2010). Correlations between structural, barrier, thermal and mechanical properties of plasticized gelatin films. Innovative Food Science and Emerging Technologies, 11(2), 369-375. https://doi.org/10.1016/j.ifset.2009.07.005
[51] Jiménez, A., Fabra, M. J., Talens, P., \& Chiralt, A. (2012). Edible and Biodegradable Starch Films: A Review. Food and Bioprocess Technology, 5(6), 2058-2076. https://doi.org/10.1007/s11947012-0835-4

[52] Dias, A., Müller, C., Larotonda, F., \& Laurindo, J. (2010). Biodegradable films based on rice starch and rice flour. Journal of Cereal Science, 51(2), 213-219. https://doi.org/10.1016/j.jcs.2009.11.014

[53] Marzo, I. (2010). Efecto del tipo y contenido de aceites esenciales sobre las propiedades mecánicas y barrera de películas comestibles bbasadas en zeina. Universidad Publica de Navarra.

[54] Pranoto, Y., Rakshit, S., \& Salokhe, V. (2005). Enhancing antimicrobial activity of chitosan films by incorporating garlic oil, potassium sorbate and nisin. LWT - Food Science and Technology, 38(8), 859-865. https://doi.org/10.1016/i.lwt.2004.09.014

[55] Valderrama, N., Algecira, N., \& Albaracín, W. (2016). Efecto del almacenamiento sobre las propiedades físicas de las películas de quitosano con inclusión de aceites esenciales de tomillo y romero. Matéria (Rio de Janeiro), 21(1), 141-156. https://doi.org/10.1590/S1517-707620160001.0013

[56] Kechichian, V., Ditchfield, C., Veiga-Santos, P., \& Tadini, C. (2010). Natural antimicrobial ingredients incorporated in biodegradable films based on cassava starch. LWT - Food Science and Technology, 43(7), 1088-1094. https://doi.org/10.1016/j.1wt.2010.02.014

[57] Bosquez-Molina, E., Ronquillo-de Jesús, E., Bautista-Baños, S., Verde-Calvo, J. R., \& Morales-López, J. (2010). Inhibitory effect of essential oils against Colletotrichum gloeosporioides and Rhizopus stolonifer in stored papaya fruit and their possible application in coatings. Postharvest Biology and Technology, 57(2), 132-137. https://doi.org/10.1016/j.postharvbio.2010.03.008

[58] Avila-Sosa, R., Hernández-Zamoran, E., López-Mendoza, I., Palou, E., Jiménez, M., Nevárez-Moorillón, G., \& López-Malo, A. (2010). Fungal inactivation by mexican oregano (lippia berlandieri schauer) essential oil added to amaranth, chitosan, or starch edible films. Journal of Food Science, 75(3). https://doi.org/10.1111/j.1750-3841.2010.01524.x

[59] Sosa, D., Trejo, M., Lira, A., \& Pascual, S. (2016). Aplicación de recubrimientos comestibles adicionados con aceite esencial de orégano en pepino (Cucumis Sativus L. ). Investigación Y Desarrollo En Ciencia Y Tecnología de Alimentos, 1(1), 90-95.

$1^{\text {th }}$ LACCEI International Multi-Conference for Engineering, Education, and Technology: "Industry, Innovation, And Infrastructure for Sustainable Cities and Communities", 24-26 July 2019, Jamaica. 